\title{
The Indira Gandhi Case and the Advocacy of Justice
}

\author{
Wan Naim Wan Mansor*
}

In the past decade or so, child custody cases among Muslim-convert and nonMuslim parents remains a controversial issue in Malaysia. The recent court judgment for the 'Indira Gandhi Case' re-highlights the issue, while spurring on a heated series of debates across the nation. Many, especially non-Muslims, have touted the latest judgment as a case of gross injustice and part of a worrisome trend of "disempowerment among non-Muslims to seek judicial redress". ${ }^{1}$

On $30^{\text {th }}$ December 2015, the Court of Appeal repealed the groundbreaking 2014 High Court judgment which quashed the conversion of Indira's three children to Islam. The unilateral conversion was filed by Indira's ex-husband, Muhammad Riduan (previously Patmanathan), soon after he left their house in 2009. As a result, the three children were officially 'Muslims' again - excluding the eldest daughter, due to her coming of age. This was despite Indira being a Hindu, and despite her being awarded custody rights by the civil Ipoh High Court. Overall, the case invoked some highly emotional responses, especially given the dramatic nature of the separation between a nursing mother and her then 11-month baby (Prasana Diksa), taken away by Riduan. Since then, the two eldest children have remained with Indira, while the youngest child has stayed with Riduan.

Minus the bureaucratic predicaments, Indira Gandhi's legal opposition to the conversion of her children seemed pretty straight-forward, and based on these reference points:

1. A Malaysian Cabinet directive, announced on $13^{\text {th }}$ April 2009, banned single-parent unilateral conversion of a child and required a converting spouse to "resolve all outstanding issues pertaining to his non-Muslim spouse and family [which includes custodial rights]...under civil law before remarrying". ${ }^{2}$ If a consensus between the parents could not be achieved, "the children should be allowed to maintain the original faith of the parents at the time of the civil marriage". 3

2. The Islamic Family Law (Perak) Enactment 2004 section 50(3)(b) states that the Syariah High Court can only hear and decide cases if all the involved parties are Muslims. A case is beyond the jurisdiction of the Syariah Court if either the plaintiff or defendants are non-Muslims, despite the subject matter (i.e. child custody) falling well within its purview. 
3. The Ipoh High Court (1 $11^{\text {th }}$ March 2010) had awarded child custody to Indira, ruling that the welfare of the children would be best catered for under her care, and due to the nature of Mr. Riduan's job (which requires him to move a lot). ${ }^{4}$ When referring to Prasana Diksa, the judge also invoked section 88(3) of the Law Reform (Marriage and Divorce) Act 1976, which provides custodial preference to mothers for children under seven years old. ${ }^{5}$

Thus, Muhammad Riduan's unilateral seizure of custodial rights and the conversion of his three children via the Syariah Court is clearly at variance with the above laws and judgments. Neither does his ex-wife, Indira Gandhi, appear to have been given her right of equal treatment under the law, since as a nonMuslim she could not participate in the Syariah court. This blindsiding is even more objectionable considering that, if the proper legal route had been taken via the civil court, Indira would have been more likely to gain custodianship of her three children (which she indeed did).

From the Islamic legal perspective, the Qur'an does not provide any clear injunction on the matter of interfaith child custody. Major historical fuqaha' provide mixed opinions on the matter: the majority opinion, represented by the Hanafi, Shafi'i, and Hanbali schools, holds that the child should follow the converted Muslim parent in all cases, whilst Maliki law submits that only the father's religion is relevant, based on the Arab tradition of inheritance and lineage. ${ }^{6}$ There are also opinions that non-Muslim parents can be granted child custody, albeit with strict requirements that prohibit the child from going to nonIslamic houses of worship and being taught 'un-Islamic' precepts and behaviors (such as drinking alcohol or eating pork). ${ }^{7}$

However, there is a single hadith in Sunan Abu Dawud, The Book of Divorce, Hadith number 2244, under chapter 25/26 "If One of The Parents Accepts Islam, Who is the Child Given to?", which directly tackles this issue:

Abu Dawud said that Ibrahim bin Musa Ar-Razi informed him, that Isa reported to him, that Abdul Hamid bin Ja'far reported from his father on the authority of his grandfather Rafi' bin Sinan, that he (Rafi' bin Sinan) accepted Islam, but his wife refused to do so. So she went to the Prophet and said: "She is my daughter, and she is weaned, or almost weaned." And Rafi' said: "She is my daughter." So the Prophet told him, "Sit on this side," and told her, "Sit on that side," and then placed the girl between them. He then said to both of them. "Call her." The girl went ${ }^{8}$ towards her mother, but the Prophet said: "O Allah! Guide her," so she went to her father, and he took her. (Hadith grade: Hasan) ${ }^{9}$ 
This interesting hadith provides invaluable guidance on the subject at hand: [1] Despite the Prophet's obvious religious inclination towards the Muslim father, the judgement process strictly adhered to the principles of equality and justice. In this case, the non-Muslim parent was given equal opportunity in front of the judge (i.e. the Prophet), who knew full well that there was a 50-50 chance that the child would go to her non-Muslim mother. The hadith therefore confirms that the religious status of a parent should not be a reason to impede equal treatment under the law. [2] The fact that the Prophet carried out this specific 'test' also suggests that the welfare of the child exceeds the importance of the religious status of the parents - apparently, in this case the 'welfare' criterion might be emotional comfort.

This principle of justice is in line with the famous Quranic verse, Chapter (4) An-Nisa; verse 135 "O you who have believed, be persistently standing firm in justice, witnesses for Allah, even if it be against yourselves or parents and relatives. Whether one is rich or poor..." This clearly instructs justice, even if it goes against one's own interests, whether familial or social. Another relevant example involves the Prophet's etiquette during the controversial Hudaybiyah Treaty. The Prophet kept true and honored this agreement, signed with the nonMuslim pagan Arabs of Mecca, despite the fact that it ostensibly put the Muslims at a disadvantage. The treaty demanded that Meccan defectors be returned to Mecca, whilst Medinan (the Muslim camp) defectors to Mecca must be left alone. Later on, the Prophet's commitment to this agreement was direly tested when he had to return Abu Jandal ibnu Suhayl ibnu Umar to the Meccans, amidst much dismay from the Muslims. ${ }^{10}$

In the Indira Gandhi case, despite the perception that giving Indira an equal opportunity under the law would result in the Malaysian Muslim community losing the three children, curbing justice by disallowing a non-Muslim to seek proper legal recourse not only contradicts the core principles of Islam but ultimately incurs further damage to Islam in the long term.

Moreover, in the Malaysian context Islam is enshrined as the religion of the federation; it is a constitutional obligation to preserve it. This constitutional providence could be manifested in the form of a law requiring children of multifaith parents to be enrolled in a national school (or any school) in which adequate exposure to Islam up to the age of 18 is provided. ${ }^{11}$ Other reasonable laws venerating the position of Islam in Malaysia, while adhering to the principles of justice, could also be introduced. This kind of mediated approach perhaps parallels the Prophet's well-placed 'interjection' of "O Allah! Guide her" in the previous hadith. 


\section{Notes}

* Wan Naim Wan Mansor is Analyst at IAIS Malaysia. He may be reached at wannaim@iais.org.my.

For a more detailed and comprehensive discussion of conversion issues and child custody in Malaysia, and recommendations of legal reforms carefully tailored to the Malaysian context, kindly refer to the inaugural IAIS Malaysia Policy Issue Paper "Conversion in Malaysia: Issues and Reform Proposals". No.1-December 2012.

1. Ting, H. (2009). The Politics of National Identity in West Malaysia: Continued Mutation or Critical Transition? Tonan Ajia Kenkyu (Southeast Asian Studies), 47(1), 31-51.

2. IAIS Malaysia Policy Issue Papers. "Conversion in Malaysia: Issues and Reform Proposals". Mohammad Hashim Kamali, Osman Bakar, Zarina Nalla, and Hafiz Hassan. No. 1-December 2012.

3. Ibid.

4. Ipoh High Court Judgement. Judicial Review No.: 25-10-2009. Page 9.

5. Ibid.

6. IAIS Malaysia Policy Issue Papers. "Conversion in Malaysia: Issues and Reform Proposals". Supra, p. 6.

7. Mohamed Azam Mohamed Adil (2014). Penentuan Agama dan Hak Penjagaan Anak-anak Menurut Undang-undang Islam. JAKIM. Page 8.

8. Another translation uses the word 'inclined' to translate the Arabic word 'بلأ', instead of 'went'. Refer: http://www.usc.edu/org/cmje/religious-texts/hadith/ abudawud/012-sat.php.

9. Abu Dawud Sulaiman bin Ash'ath, edited \& referenced by Abu Tahir Zubair Ali Za'I, translated by Nasiruddin Al-Khattab, final review by Abu Khalyl. (2008). Sunan Abu Dawud: English Translation of Sunan Abu Dawud. Riyadh: Darussalam. Hadith \#2244.

10. Amuda, Yusuff Jelili and Lazim, Ahmad Sohaimi. Application of the Hudaybiyah Treaty in the Contemporary Issues: Case Study of Multiracial Society in Malaysia (January 26, 2012). OIDA International Journal of Sustainable Development, Vol. 3, No. 3, pp. 51-66, 2012. Available at SSRN: http://ssrn.com/abstract=1992547

11. IAIS Malaysia Policy Issue Papers. "Conversion in Malaysia: Issues and Reform Proposals". Supra, p. 12. 